\title{
Political Instability and Growth: The Central African Republic
}

\author{
Dhaneshwar Ghura and \\ Benoît Mercereau
}




\title{
IMF Working Paper
}

African and Asia and Pacific Departments

\section{Political Instability and Growth: The Central African Republic}

\author{
Prepared by Dhaneshwar Ghura and Benoît Mercereau ${ }^{1}$ \\ Authorized for distribution by Jean A.P. Clément and Alessandro Zanello
}

May 2004

\begin{abstract}
This Working Paper should not be reported as representing the views of the IMF. The views expressed in this Working Paper are those of the author(s) and do not necessarily represent those of the IMF or IMF policy. Working Papers describe research in progress by the author(s) and are published to elicit comments and to further debate.

This paper provides empirical evidence that the propensity for political instability in the Central African Republic (C.A.R.) has been increased by low tax revenues and deteriorations in the terms of trade. The direct effect of political instability on economic growth is not statistically significant, once account is taken of domestic investment, and economic growth in neighboring countries. The policy implications are: (i) mobilization of domestic revenues to pay public employees' salaries and provide basic social services would lower the probability of coups; (ii) economic diversification would reduce the propensity for adverse terms of trade shocks to fuel coups; and (iii) neighboring countries' efforts to resolve conflicts and achieve sustained growth would be beneficial for the C.A.R.'s economic performance.
\end{abstract}

JEL Classification Numbers: O4; O55

Keywords: Political instability; Economic Growth; Conflicts; External Shocks

Author’s E-Mail Address: dghura@imf.org; bmercereau@.imf.org

\footnotetext{
${ }^{1}$ Benoît Mercereau was in the Equatorial I Division of the African Department when this paper was written. The authors would like to thank Donal Donovan, Jean Clément, Robert Flood, Mark Lewis, Jacob Gons, Ragnar Gudmundsson, Bernardin Akitoby, and Jean-Claude Nachega for useful comments. The authors are grateful to Stéphanie Denis for invaluable research assistance. This paper will be published in a forthcoming book entitled From Conflict to Reconstruction-Main lessons and challenges for Sub-Saharan Africa-The case of the Democratic Republic of the Congo.
} 


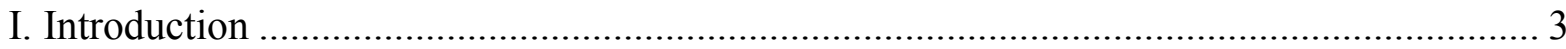

II. Economic and Political Performance Since Independence ......................................... 4

A. Summary of economic performance ...................................................................... 4

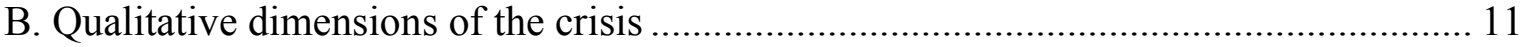

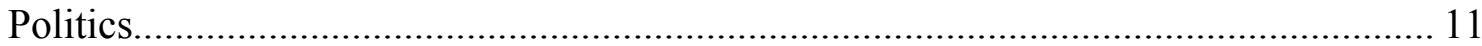

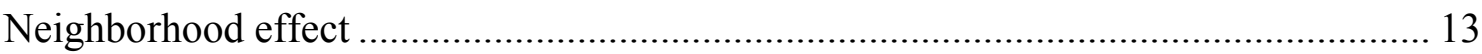

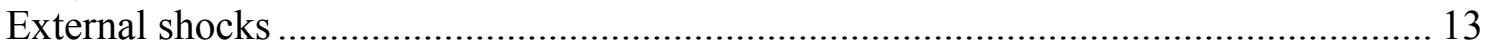

III. Empirical Analysis of the Determinants of Political Instability .................................. 14

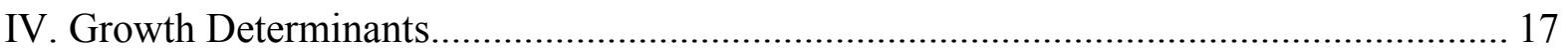

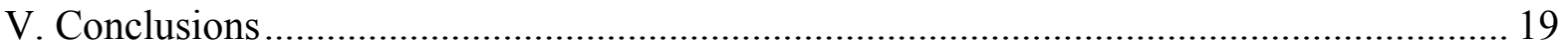

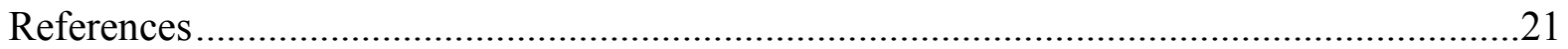

Figures

1. Central African Republic: Per Capital Real GDP, 1960-2002 …..................................7

2. Central African Republic: Domestic Investment, 1960-2002 _..........................................7

3. Central African Republic: Budgetary Performance, 1966-2002 .......................................8

4. Central African Republic: Terms of Trade and Real Effective Exchange Rate,

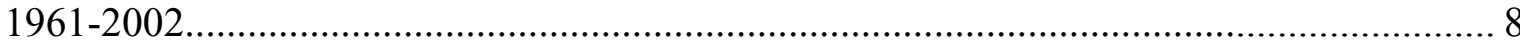

5. Central African Republic and Neighboring Countries: Per Capita GDP, 1960-2002 ......... 9

6. Central African Republic: Predicted Probability of an Attempted Coup or Rebellion,

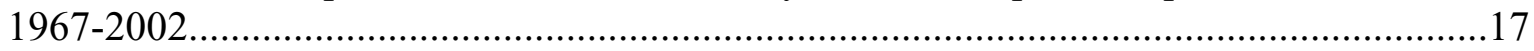

Tables

1. Central African Republic: Chronology of Key Events Since Independence.......................5

2. Central African Republic and Sub-Saharan Africa: Comparative Economic and Social Performance

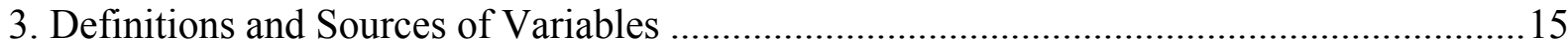

4. Central African Republic: Probit Estimation of the Propensity of Political Instability........16

5. Central African Republic: Determinants of Economic Growth, 1967-2002 ......................19 


\section{INTRODUCTION}

The Central African Republic (C.A.R.), a landlocked nation, is one of the poorest countries in the world. It ranked 168th out of 175 countries listed in the 2003 United Nations Development Program Human Development Index. The C.A.R.'s resident population was estimated at about 3.9 million in 2002, the vast majority of whom live in rural areas and depend on food and cash crops and livestock for their livelihood. The country is endowed with considerable water and mineral resources, and has untapped potential for agriculture. The economy is highly dependent on diamonds and timber. Key constraints on sustained economic growth include political instability, weak governance, a low level of human capital, inadequate infrastructure, and conflicts in neighboring countries. Progress under various attempts to set the economy on a sustainable development path has been uneven, and the country's economic performance since independence has been weak.

The political situation in the C.A.R. has been characterized by recurrent instability, with a dozen coup attempts or mutinies recorded since independence (see Table 1 for a chronology of key events). Such instability has undermined homegrown efforts to escape a trap revolving around poverty and poor governance. To understand the root causes of instability would therefore be key to setting the country back on a sustainable development path. This paper examines the following points: (i) the possible qualitative explanations of the country's political instability and poor economic performance; (ii) the empirical determinants of political instability in the country; and (iii) empirical factors (including political instability) that have influenced economic growth.

A number of papers have been written on the subject of conflicts. ${ }^{2}$ Gudmundsson (2004) provides an excellent survey of the literature on the causes and consequences of conflicts. In general, the empirical work finds that the risk for increased conflicts are explained primarily by economic factors (such as initial income, dependence on commodity exports, and economic growth in the preceding period), but also by noneconomic factors (such as social fractionalization). Other studies point to spillover of regional conflicts on the economic performance of a given country (e.g., Sambanis, 2003). Conflicts in neighboring countries also heighten the risk that the country itself will fall into civil war (Collier and others, 2003). The paper by Yartey (2004), focusing on data from sub-Saharan Africa, finds that conflicts in the region are caused by low economic growth and weak institutions.

The analysis in this paper shows, first, that the propensity for political instability has been increased by past low tax revenue, as well as by deteriorations in the terms of trade. Weak revenue performance undermines the ability of the government to pay the salaries of civil servants and to provide basic social services, which raises frustrations among the population and triggers political instability. Insufficient economic diversification also leaves the country vulnerable to terms of trade shocks, increasing not only economic, but also political volatility. These results seem to suggest that efforts to enhance the country's

\footnotetext{
${ }^{2}$ See, for example, Collier (1999), Collier and others (2003), Easterly and Levine (1997), Elbadawi and Sambanis (2000), and Sambanis (2003).
} 
capacity to mobilize revenue would be critical in lowering the propensity for political instability. In addition, the diversification of the Central African Republic's economic base would not only make its economy less vulnerable to external shocks, but would also reduce the propensity of terms of trade shocks to fuel domestic conflict. A second conclusion from the empirical investigation is that the direct impact of political instability on growth is not significant, once an account is made of domestic investment in the C.A.R. and economic performance in neighboring countries.

The next section examines economic and political developments since 1960. Section III investigates the determinants of political instability, and Section IV analyzes the determinants of growth. Section V concludes the paper.

\section{Economic and Political Performance Since Independence}

\section{A. Summary of economic performance}

Since gaining independence in 1960, the C.A.R. ${ }^{3}$ economy has intermittently been adversely affected by political instability and social unrest, undermining various attempts to set the economy on a sustainable development path. Military coups, army mutinies, and extended labor disputes, combined with poor macroeconomic management and weak governance, have prevented the development of the country's rich and diverse endowment in natural resources and led to deteriorating economic and social performance. In particular, the chronic weak revenue performance led to the accumulation of domestic wage and external debt arrears, as well as the degradation of basic social services. The country's woes have been compounded by a significant downward trend in its terms of trade since 1977. The accumulation of large arrears on and the irregular payments of wages to civil servants and military personnel have led to prolonged labor strikes and army mutinies. In spite of the C.A.R.'s efforts to pursue a democratization process in the 1990s, including the successful completion of two rounds of contested legislative and presidential elections in 1993 and 1999, the political situation was tenuous throughout the 1990s. By the late 1990s, the country was caught in a domestic and external debt trap, accentuating the dissatisfaction of the population - stemming from the wage arrears and deterioration in services - and the propensity for attempts to remove the presidency by military means.

${ }^{3}$ The C.A.R. is a member of the French franc zone. Its currency, the franc de la Communauté Financière Africaine (the CFA franc), is issued by the Banque des États de l'Afrique Centrale (BEAC), and has been pegged to the euro since January 1999 at the fixed rate of $€ 1=\mathrm{CFAF}$ 655.957. The BEAC is the central bank for six African countries - Cameroon, Central African Republic, Chad, Congo, Equatorial Guinea, and Gabon. The other members of the CFA franc zone are Benin, Burkina Faso, Côte d'Ivoire, Niger, Senegal, Togo, and, since 1984, Mali, whose common central bank is the Banque Centrale des États de l'Afrique de l'Ouest. 
Table 1. Central African Republic: Chronology of Key Events Since Independence ${ }^{4}$

\section{Independence}

1960: The C.A.R. becomes independent with David Dacko as president.

1962: Dacko turns the C.A.R. into a one-party state.

1964: Dacko confirmed as president in elections in which he is the sole candidate.

\section{Bokassa presidency}

1965: Dacko is ousted by the army commander, Jean-Bédel Bokassa, as the country faces bankruptcy and a threatened nationwide strike.

1972: Bokassa declares himself president for life.

1977: Bokassa proclaims himself emperor and renames the country the "Central African Empire."

\section{Dacko and Kolingba presidency}

1979: Bokassa is ousted in a coup led by Dacko and backed by French troops after widespread protests in which many schoolchildren are arrested and massacred while in detention.

1981: Dacko presidency is deposed in a coup led by the army commander, André Kolingba.

1984: Amnesty for all political party leaders is declared.

\section{Transition to democracy and Patassé presidency}

1991: Political parties are permitted to form.

1992 October: Multiparty presidential and parliamentary elections are held in which Kolingba came in last, but are annulled by the supreme court on the grounds of widespread irregularities.

1993: Ange-Félix Patassé defeats Kolingba and Dacko in elections to become president, ending 12 years

of military rule. Kolingba releases several thousand political prisoners, including Bokassa, before stepping down as president.

1996 May: Soldiers stage an uprising in the capital, Bangui, over unpaid wages.

1997 November: Soldiers stage more revolts.

1997: France begins withdrawing its forces from the republic; African peacekeepers replace French troops. 1999: Patassé is re-elected president.

2000 (December): Civil servants stage general strike over back pay; rally organized by 15 opposition groups who accuse President Patassé of mismanagement and corruption deteriorates into riots.

2001 (May): At least 59 are killed in an abortive coup attempt by former president André Kolingba.

President Patassé suppresses attempt with help of Libyan and Chadian troops as well as Congolese rebels. The political upheaval increases economic instability.

2001 (November): Clashes break out as troops try to arrest sacked army chief of staff General François Bozizé who is accused of being involved in the May coup attempt. Thousands flee fighting between government troops and Bozizé's forces, while envoys from Chad, Libya, and the United Nations try to resolve the conflict.

2002 (May): Government lifts curfew imposed after May 2001 coup attempt to signal return of "security and peace" and anticipates return of foreign investors.

2002 (October): After six days of heavy fighting in Bangui, Libyan-backed forces and troops led by JeanPierre Bemba from the Democratic Republic of the Congo (DRC) help to subdue an attempt by forces loyal to dismissed army chief General Bozizé to overthrow President Patassé. Relations with neighboring Chad, accused by Bangui of helping Bozizé, worsen.

2003 (February): General Bozizé's troops make a significant advance to capture key strategic cities outside Bangui in the northern part of the C.A.R..

2003 March: General Bozizé mounts a successful coup while President Patassé is out of the country and declares himself President.

\footnotetext{
${ }^{4}$ Source: http://news.bbc.co.uk/1/hi/world/africa/country_profiles/1067615.stm.
} 
Table 2: Central African Republic and Subsaharan Africa, Comparative Economic and Social Performance (Average during 1990-2000; in units indicated)

\begin{tabular}{|c|c|c|}
\hline & CAR & SSA \\
\hline \multicolumn{3}{|l|}{ Economic performance } \\
\hline GDP per capita (constant 1995 US dollars) & 332 & 559 \\
\hline GDP growth (annual percent change) & 1.4 & 2.1 \\
\hline GDP per capita growth (annual percent change) & -0.9 & -0.5 \\
\hline Tax revenue (in percent of GDP) & 8.0 & 20.9 \\
\hline Gross domestic savings (in percent of GDP) & 4.0 & 15.7 \\
\hline Gross domestic investment (in percent of GDP) & 11.4 & 16.7 \\
\hline Trade in goods (in percent of GDP) & 25.7 & 46.9 \\
\hline \multicolumn{3}{|l|}{ Cost structure } \\
\hline Telephone average cost of local call (US\$ per three minutes) & 0.71 & 0.08 \\
\hline \multicolumn{3}{|l|}{ External assistance } \\
\hline Aid (in percent of GNI) & 13.4 & 5.7 \\
\hline \multicolumn{3}{|l|}{ Physical infrsatructure/technology } \\
\hline Roads, paved (in percent of total roads) & 2.3 & 14.9 \\
\hline Mobile phones (per 1000 people) & 0.3 & 3.6 \\
\hline Personal computers (per 1000 people) & 1.4 & 8.1 \\
\hline \multicolumn{3}{|l|}{ Social performance } \\
\hline Adult illiteracy rate (in percent of people ages 15 and above) & 60.1 & 44.3 \\
\hline Primary school enrollment ratio & 57.7 & 75.0 \\
\hline Secondary school enrollment ratio & 10.1 & 24.6 \\
\hline Tertiary school enrollment ratio & 1.5 & 3.4 \\
\hline Immunization, DPT (in percent of children under 12 months) & 53.6 & 51.5 \\
\hline Infant mortality rate (per 1000 live births) & 97.9 & 96.7 \\
\hline Life expectancy at birth ( in years) & 45.7 & 48.9 \\
\hline
\end{tabular}

The C.A.R. has been left behind in comparison with the group of sub-Saharan African countries (Table 2). During the period 1990-2000, the average economic, social, and infrastructure indicators for the C.A.R. were weaker than the average for sub-Saharan African countries, despite receiving larger amounts of foreign aid. Life expectancy at birth, currently at about $43 \frac{1}{2}$ years, has been on a declining trend since 1990 and is among the lowest in sub-Saharan Africa. According to a recent report by the UN Conference on Trade and Development, about 70 percent of the population live on less than $\$ 1$ per day (and about 86 percent live on less than $\$ 2$ per day).

Per capita real GDP has been falling virtually continuously since 1977; notwithstanding the recent rise in output, per capita real GDP in 2002 was about two-thirds of its level in 1977. The nature of the crisis in the Central African Republic is illustrated in Figures 1-4 and is best understood by focusing on the various presidencies that ruled the country since 1960: 
Figure 1. Central African Republic: Per Capita Real GDP, 1960-2002 (In 1987 CFA francs; index 1960=100)

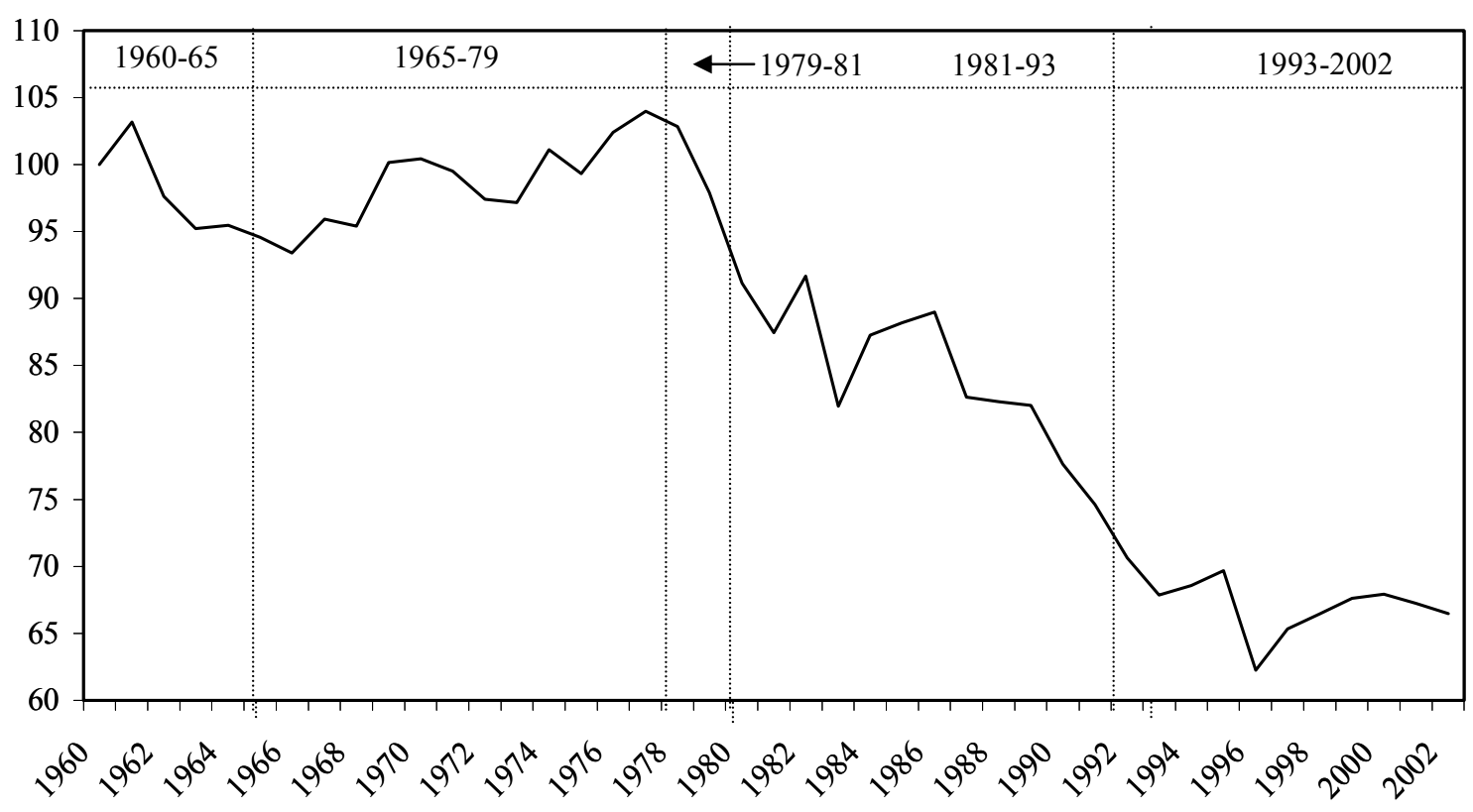

Sources: World Bank World Development Indicators and IMF World Economic Outlook databases.

Figure 2. Central African Republic: Domestic Investment, 1960-2002 (In percent of GDP)

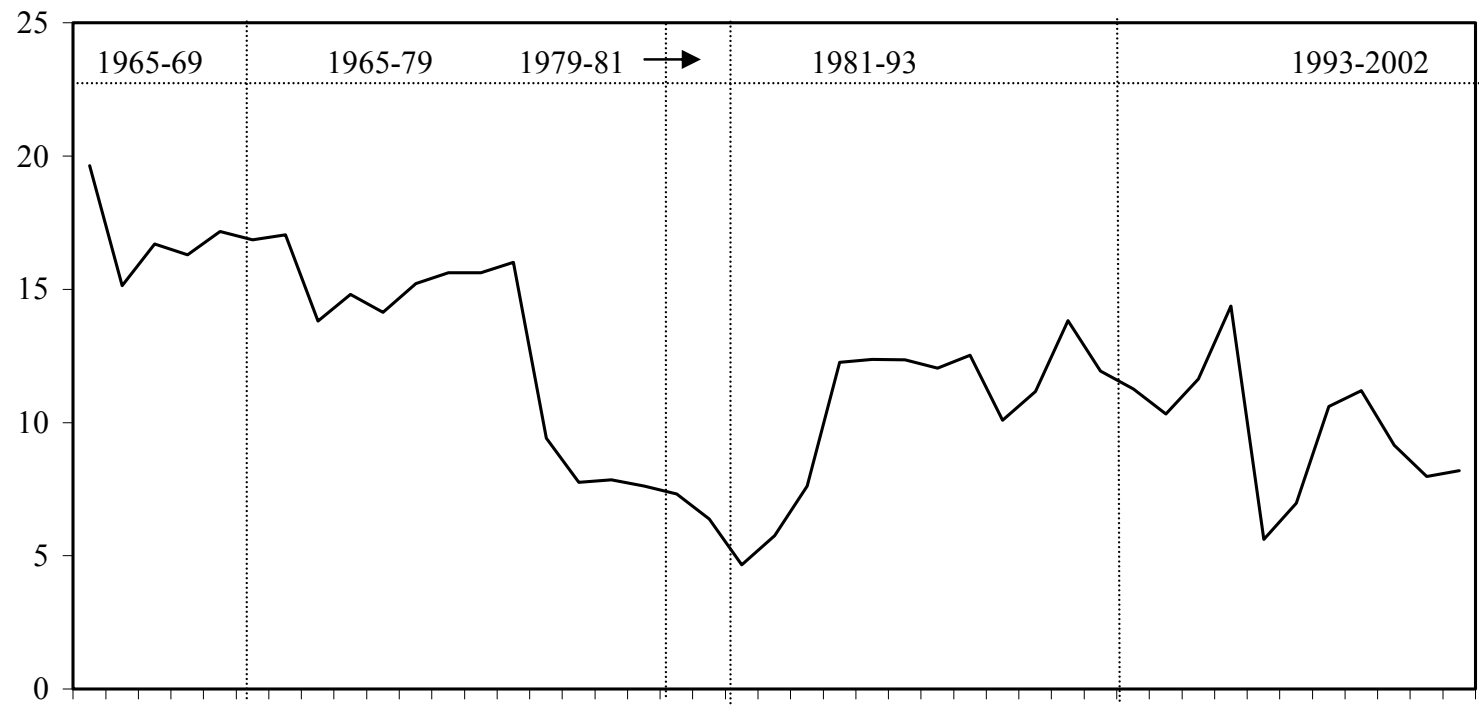

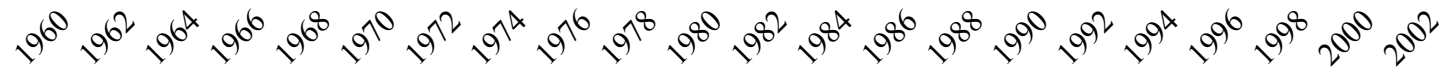

Sources: World Bank World Development Indicators and IMF World Economic Outlook databases. 
Figure 3. Central African Republic: Budgetary Performance, 1966-2002 (In percent of GDP)

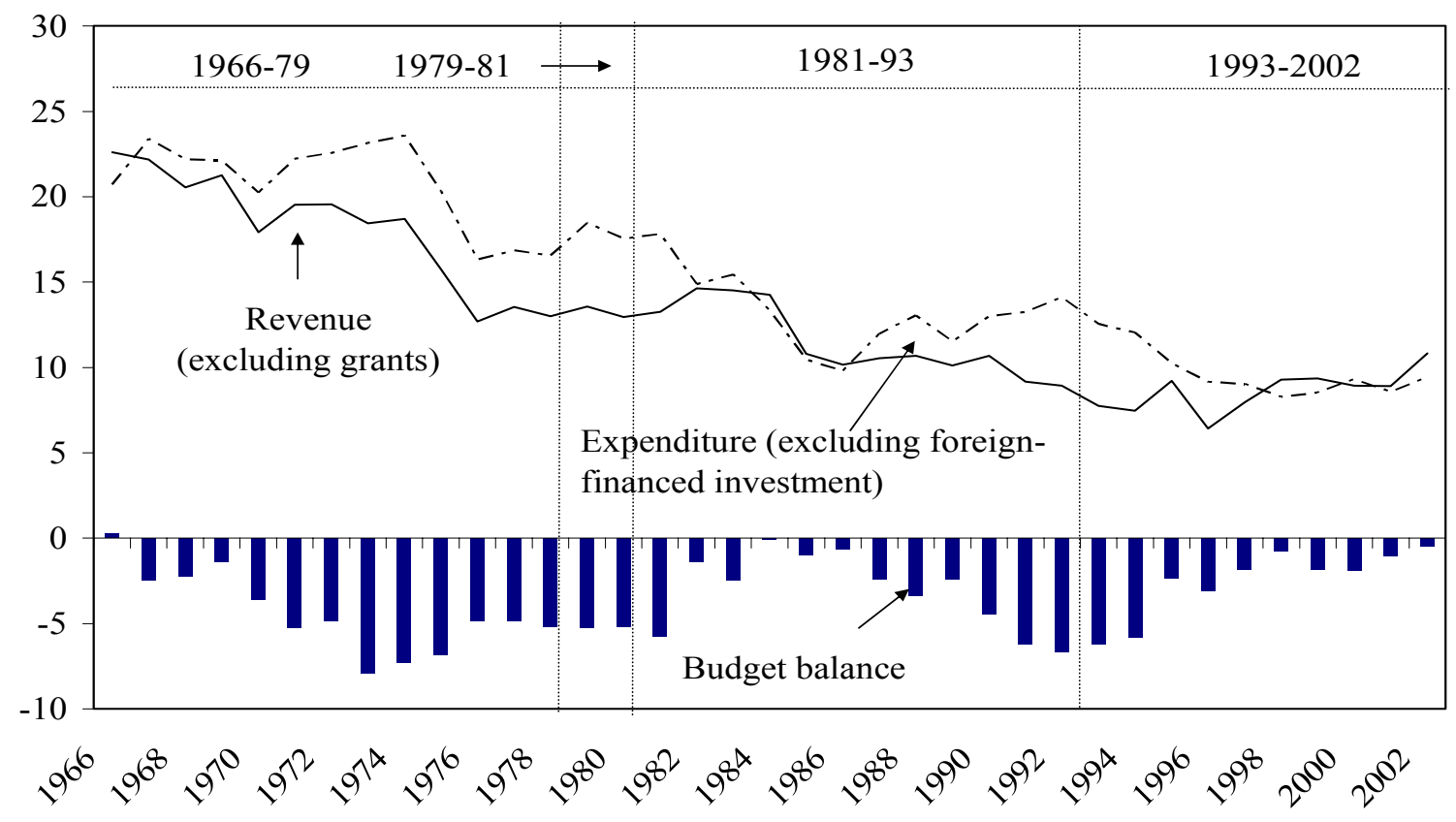

Sources: World Bank Development Indicators and IMF World Economic Outlook databases.

Figure 4. Central African Republic: Terms of trade and Real Effective Exchange Rate, 1961-2002 (Index 1990=100)

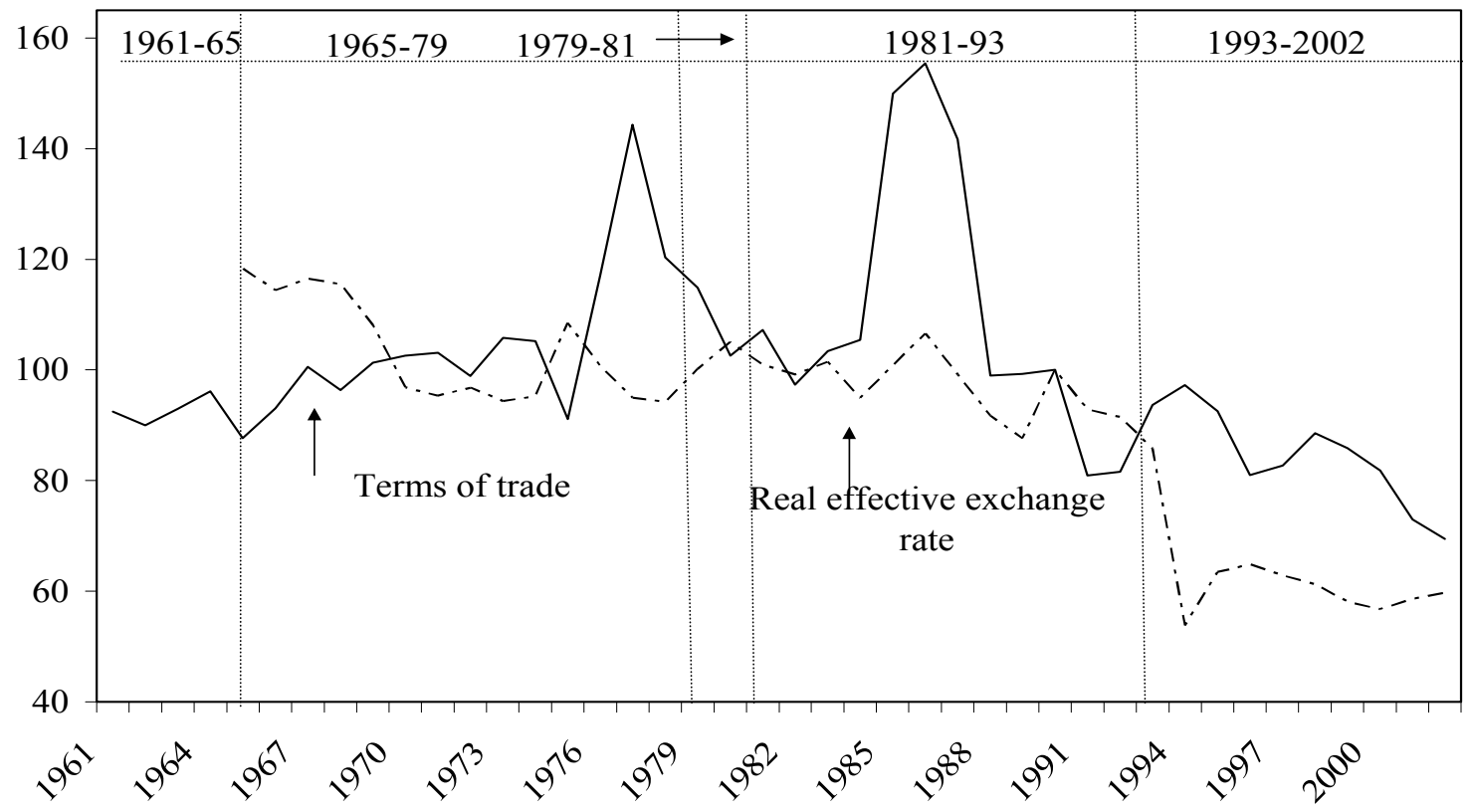

Sources: World Bank Development Indicators and IMF World Economic Outlook databases. 
Figure 5. Central African Republic and Neighboring Countries: Per Capita GDP, 1960-2002 1/ (Index 1960=100)

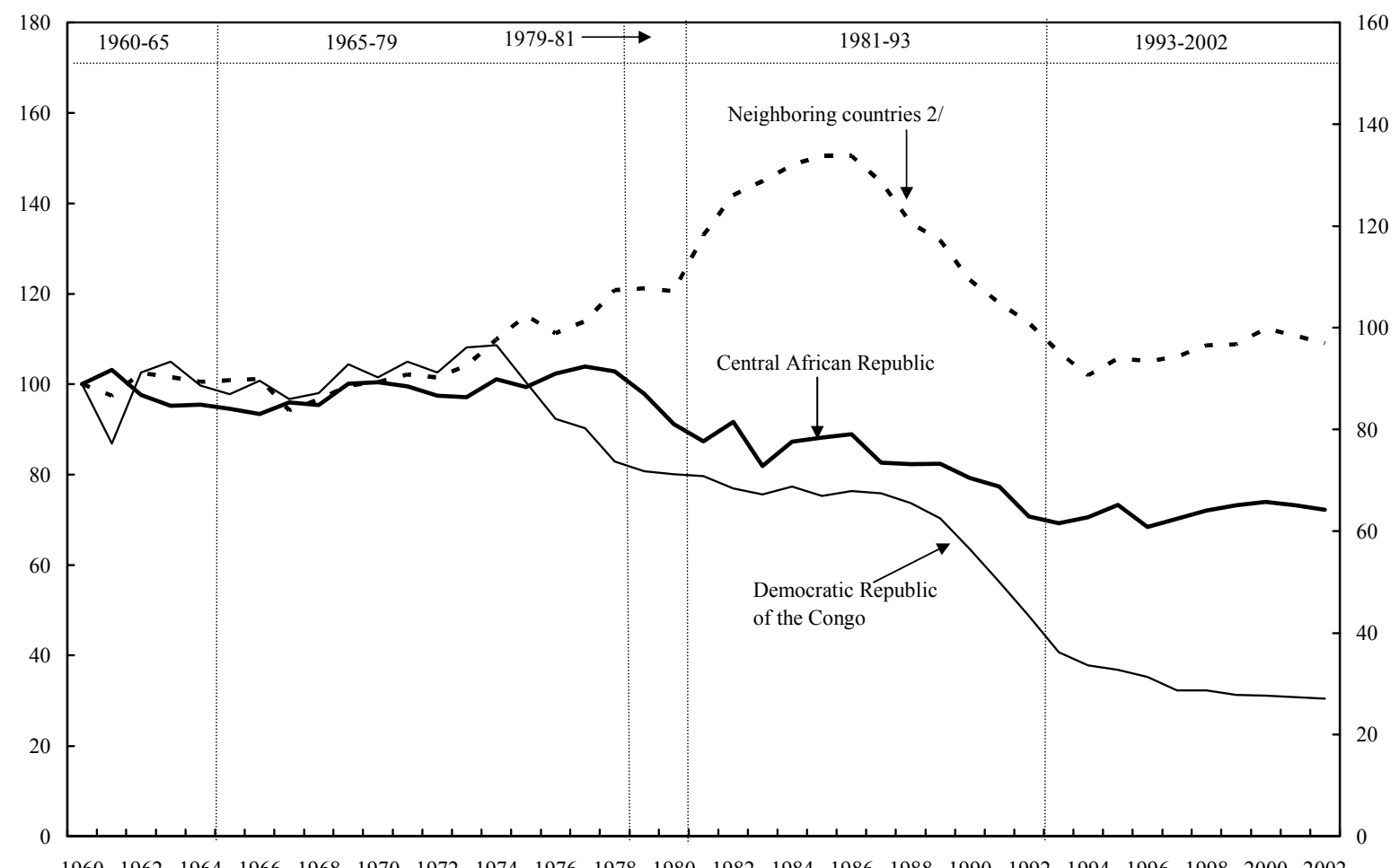

$\begin{array}{llllllllllllllllllllll}1960 & 1962 & 1964 & 1966 & 1968 & 1970 & 1972 & 1974 & 1976 & 1978 & 1980 & 1982 & 1984 & 1986 & 1988 & 1990 & 1992 & 1994 & 1996 & 1998 & 2000 & 2002\end{array}$

Source: World Bank World Development Indicators and IMF World Economic Outlook databases.

1/ Based on per capita GDP expressed in 1995 U.S. dollars.

2/ Based on weighted per capita GDP (expressed in 1995 U.S. dollars) of the Democratic Republic of the Congo, Cameroon, Chad, the Republic of Congo, and Sudan. 
- Dacko presidency (1960-65): Per capita real GDP fell by about 5 $1 \frac{1}{2}$ percent on a cumulative basis, despite the large increase in the capital stock per person and the relative stability of the terms of trade. President Dacko was ousted by Jean-Bédel Bokassa, the army commander, in 1965 as the country faced bankruptcy and there were increasing signs of tensions from the part of the labor unions.

- Bokassa presidency (1965-79): During the period 1965-77, per capita real GDP increased by about 10 percent on a cumulative basis. This was to a large extent owing to a program launched by the President ("Opération Bokassa") to ensure adequate supplies of food crops, improve yields of export crops, and achieve a measure of diversification. This program received generous financial assistance from the international donor community. It appears that 1977 marked a turning point in the economic performance of the country; President Bokassa, who had already declared himself president for life in 1972, proclaimed himself emperor in 1977. The year 1977 also marks the start of a downward trend in the country's terms of trade. As the Bokassa presidency became much more repressive and brutal, foreign assistance to the country dwindled, and the country's capital stock per person started declining. By the end of this presidency, per capita real GDP also started falling, as did domestic revenue and expenditures. In 1979, Bokassa was ousted by David Dacko, the former President, after widespread protests in which many schoolchildren were massacred.

- Dacko presidency (1979-81): The slide in both per capita capital stock and per capita real GDP continued, with the latter falling by almost 11 percent during 1979-81. In 1981, President Dacko was deposed in a coup led by the army commander, André Kolingba.

- Kolingba presidency (1981-93): The country remained highly dependent on foreign aid. The slide in the capital stock on a per capita basis continued. While the revenue-GDP ratio increased during 1981-84, it resumed its downward trend in the mid-1980s when the country's terms of trade declined sharply, reportedly compounded by the smuggling of diamonds. While an effort was made in the mid-1980s to bring the budget deficit under control, the need to jump-start the economy gave rise to an increasing expenditure-GDP ratio during 1986-91. The early 1990s was a tumultuous period for the C.A.R. as it underwent a protracted transition to democracy. Social tensions emerged in 1991 when a conflict with the labor movement led to a protracted general strike. As the public administration was paralyzed, tax collections fell, depriving the government of the resources needed to meet domestic and external financial obligations. In particular, the government could not pay salaries on a regular basis, and arrears were accumulated. The country also suffered from an overvaluation of the CFA franc, which caused a sharp decline in the exports of coffee, cotton, and timber.

- Patassé presidency (1993-March 2003): Following one set of elections in 1992 that was annulled by President Kolingba on the grounds of irregularities, in 1993 
Ange-Félix Patassé defeated Presidents Kolingba and Dacko to win the democratically held elections. By the time President Patassé took office, per capita real GDP was in a tailspin and the budget deficit was large. Per capita real GDP in 1993 was about two-thirds of its level in 1977. This had been accompanied by a significant decline in the per capita capital stock during the same period. Notwithstanding a number of setbacks, a series of efforts to put the economy back on track, especially since 1998, started showing some results in terms of a slowly rising trend in revenues and fiscal consolidation. The decline in per capita real GDP was arrested in the mid-1990s, including by way of the boost provided by the devaluation of the CFA franc in 1994. Nonetheless, the propensity for attempted coups and civil disturbances accentuated under the Patassé presidency. There was general dissatisfaction on the part of the population relating to massive wage arrears and the deterioration in services. The Patassé presidency was ended in March 2003 by a coup conducted by General Bozizé.

\section{B. Qualitative dimensions of the crisis}

\section{Politics}

An interesting feature of the C.A.R.'s political history over the past three decades or so relates to the fact that a few key personalities (Ange-Félix Patassé, François Bozizé, André Kolingba, and David Dacko) have been consistently the major players on the political scene. President Patassé was prime minister under President Bokassa in the late 1970s, and had himself staged an unsuccessful coup attempt in 1982 with General Bozizé. Mr. Kolingba seized power by force in 1981 and was President of the C.A.R. from 1981 to 1993; strong internal opposition forced this President to organize elections in the early 1990s. President Kolingba ran unsuccessfully for the presidency under democratically held elections in 1992; he was also involved in the May 2001 attempted coup. David Dacko, President of the C.A.R. during 1979-81, lost to President Patassé the democratically held elections in 1993.

Mr. Bozizé, the author of the successful coup bid in March 2003, was an army general under President Bokassa in 1978, Defense Minister under President Dacko in 1979, and army chief under President Patassé.

A possible fundamental explanation for the rise in political instability in the Central African Republic since independence lies in the search for rents in this diamond-rich nation. Another possible reason, which became more significant in the second half of the 1990s and early 2000 s, relates to the widespread dissatisfaction of the population due to the accumulation of wage arrears and the decline in government services stemming from the lack of resources. In addition, the fact that the C.A.R. is in the middle of an unstable region has served to aggravate the inherent instability in the country. Ethnic tensions also played a role. Furthermore, the country's terms of trade have been on an almost secular downward trend since 1977.

\section{Rent seeking}

It is now well documented in the empirical literature that abundant natural resources (such as diamonds and oil) retard economic growth through political economy effects (e.g., 
Tornell and Lane, 1999) and increases corruption (Mauro, 1995; and Leite and Weidmann, 1999). It is commonly understood that a primary channel of transmission from natural resources to poor economic performance is the fact that policymakers spend a significant amount of time on maximizing the associated rents from these resources for themselves and their associates. By implication, it also means that there may be intense competition by those close to power to access these scarce resources for personal and political gains. Collier and Hoeffler (2002) have shown that natural resources considerably increase the chances of civil conflict since the available rents can be used to finance rebellions. They estimate that countries with natural resources have a much larger probability of experiencing conflicts than those that do not.

While it has not been formally documented, the rents available from the abundance of natural resources may have been an incentive to seize power. While diamonds (and, in recent years, timber) have been a source of wealth for the country, they have also been a source of fraud and corruption. Diamonds are valuable and easy to carry; it is well known that buyers in Antwerp, Belgium, have for years been declaring diamond imports from the C.A.R. that are higher than the country's reported exports. It is believed that this may be due to smuggling, sale of DRC or Angolan "conflict" diamonds via Bangui, and diamonds from non-African countries registered as those from the C.A.R. ${ }^{5}$ Diamonds have allegedly been used by politicians to grease their patronage network. The abundance of natural resources also provides incentives for foreign players to get involved in the country, further complicating the security situation.

\section{Ethnic tensions}

The empirical literature has identified ethnolinguistic fractionalization (the probability that two randomly selected people from a country will not belong to the same ethnic or linguistic group) as a deterrent to growth (Sachs and Warner (1997)); these authors report that this probability is 83 percent in the C.A.R. versus an average of $64 \frac{1}{2}$ percent for sub-Saharan Africa. Indeed, it appears that ethnic considerations have been an aspect of the political scene in the C.A.R. in the last two decades. It is interesting to note that the first four presidents of the C.A.R. came from the south. Former President Kolingba, by naming several Yakomas to key positions, was instrumental in starting the process of organizing a regime partially along ethnic lines. By the end of his presidency, over two-thirds of the army soldiers were Yakomas. Former President Patassé, who comes from the north, followed this policy by appointing northerners to top jobs. By way of illustration, the top three political positions in the country (president, prime minister, and speaker of the National Assembly) were all filled by people from the same region as President Patassé (Ouham-M'pende). The organization of the presidency along ethnic lines was also apparent in the judiciary and among the managers of public companies.

Perhaps the most destabilizing aspect of the ethnic rift was the role of ethnic issues in the army. Since some soldiers put ethnic loyalty ahead of constitutional order, politicians

${ }^{5}$ See Dietrich (2002, pp. 18-23). 
relied on them to try to seize power by unconstitutional means. Ethnic considerations seem to have played a role in the May 2001 attempted coup. At that time, a majority of soldiers were Yakomas. It is widely believed that former President Kolingba, a Yakoma, who staged the unsuccessful coup, benefited from this ethnic connection to secure support from some soldiers. It appears, however, that the military events of late 2002 and early 2003 did not have a strong ethnic dimension. Former army chief of staff François Bozizé, a Gbaya, also comes from the north.

While ethnic considerations probably contributed to the country's problems, their importance should nevertheless not be overstated. The results of the empirical work undertaken by Collier and others (2003) — using the episodes of 52 civil wars that occurred between 1960 and 1999 - show that ethnic diversity does not increase the likelihood that a country will fall into civil war. In addition, Collier and Hoeffler (2002) show that while ethnic diversity reduces the risk of conflict, there is a systematically higher risk of conflict in countries where one ethnic group represents 45-90 percent of the population.

\section{Neighborhood effect}

Recent research points to spillover effects of regional conflicts on the economic performance of a given country (Sambanis, 2003). Conflicts in neighboring countries also heighten the risk that the country itself will fall into civil war (Collier and others, 2003). Indeed the C.A.R. is surrounded by Chad (to the north), Sudan (to the east), the Democratic Republic of the Congo and the Republic of Congo (to the South), and Cameroon (to the west); most of these countries have witnessed civil conflicts at one time or another during the period 1960-2002. In addition, the conflicts in neighboring countries have provided politicians with potential military allies. For example, former President Patassé had received support from the Mouvement de Libération Congolais (MLC), a Congolese rebel movement led by Jean-Pierre Bemba and based in the neighboring Democratic Republic of the Congo (DRC). The MLC troops helped his presidency fight off the May 2001 and October 2002 coup attempts. President Patassé had also used Mr. Miskine, a Chadian rebel, as an ally. Partly as a consequence, Chad had temporarily provided asylum to General Bozizé, the former C.A.R. army chief of staff who claims responsibility for the October 2002 coup attempt, and who eventually seized power in March 2003. It is also reported that the discovery of oil in Chad aggravated long-standing differences between the C.A.R. and Chad. Being a landlocked country, the C.A.R. depends on the DRC, the Congo, and Cameroon for access to ports via land or river. Conflicts in the DRC and the Republic of Congo can have serious adverse effects on the C.A.R. For example, in 2000, the civil unrest in the DRC prevented transport of goods by boat over the Congo and Oubangui rivers, which necessitated more expensive transport by road via Cameroon.

\section{External shocks}

Diversification of the economy has been limited, and the industrialization process, which is hindered by high transportation and energy costs, remains slow. The country's heavy dependence on two principal export commodities (diamonds and timber) and imported oil, makes the economy vulnerable to terms of trade shocks (Figure 4). Following a secular rise between 1961 and 1977, the country's terms of trade declined in an almost secular way, 
with the exception of the period 1985-87. The terms of trade and the per capita real GDP fell by about 52 percent and 36 percent, respectively, during 1977-2002. Thus, the sharp deterioration in the C.A.R.'s terms of trade can explain part of the severe output decline since 1979 , but this explanation is mitigated by the secular depreciation in the country's real effective exchange rate since then, an outcome that counteracted part of the adverse effect of the terms of trade decline.

\section{Empirical Analysis of the Determinants of Political Instability}

Leaving aside the qualitative factors noted above, this section seeks to analyze empirically the possible quantifiable factors behind the C.A.R.'s political instability. ${ }^{6}$ Some studies, such as Collier and others (2003), have found that poor economic performance raises the risk of a civil conflict. In the case of the C.A.R., this could well happen through the following circumstances. First, weak economic growth breeds frustration among the population, thus providing a fertile ground for a coup attempt. Second, low tax revenue, stemming from weak economic activity, may lead to the accumulation of arrears on the salaries of public employees (including especially soldiers' salaries) and create unrest and/or rebellions. This is often cited as a reason behind military conflicts in the second half of the 1990 s and early 2000s. Lack of resources also reduces the ability of the government to provide basic social services and security.

In order to test the above-mentioned hypotheses, a Probit model is estimated with data from the C.A.R. during 1967-2002. The model assesses the probability of a coup as a function of the previous year's real GDP growth rate, tax revenue (as a percent of GDP), changes in the terms of trade, and political instability. A priori, the direction of the impact of a coup in the previous year is unclear. The model could raise the possibility of a coup in view of the destructive effect conflicts have on the county's institutions, or it could lower the possibility in view of the end of destabilizing activities after a successful coup.

There is a potential endogeneity issue in the case of the relationship between revenue performance and political instability. It could be argued that low revenue is a consequence of political instability. Repeated coups undermine institutions, thus weakening the ability of the government to raise revenue. In order to test for this effect, we run a (2-lag) Vector Auto Regression with revenue, GDP growth, political instability, and investment. This allows for a test of whether some of the variables used might help predict revenues. The results show that revenues are weakly exogenous to the system, suggesting that at an annual frequency political instability does not lead to low revenues.

The data were spliced from the series obtained from the International Monetary Fund World Economic Outlook and the World Bank World Development Indicators databases (see Table 3). The index of political instability is a dummy variable that takes a value equal to 1 in years during which there has been at least one attempted coup and zero otherwise. (We do not distinguish between failed and successful attempts.)

${ }^{6} \mathrm{An}$ indicator of corruption is not available for the CAR. 
Table 3. Definitions and Sources of Variables

\begin{tabular}{ll} 
Variable & Definition \\
\hline$G$ & Real GDP growth. \\
$g$ & Per capita real GDP growth. \\
InvY & Investment as a ratio to GDP (in constant terms). \\
BudY & Budget balance as a percent of GDP. \\
$R E R g$ & Rate of change of real effective exchange rate . \\
TOTg & Rate of change of the terms of trade. \\
$P I$ & Dummy variable measuring political instability $\left(P I_{t}=1\right.$ in years in which there is an \\
& attempted coup or a rebellion; $P I_{t}=0$ otherwise). \\
C & An indicator of possible economic or political contagion from border countries \\
& (Cameroon, Chad, Congo, the DRC, and Sudan). Measured as the growth rate of the \\
& weighted per capita real GDP of these countries expressed in 1995 constant U.S. dollars. \\
& The 1995 GDP weights are as follows: Cameroon (0.32), Chad (0.06), Republic of Congo \\
Popug & (0.10), the DRC (0.23), and Sudan (0.29). \\
revY & Population growth. \\
& Government revenue as a ratio to GDP.
\end{tabular}

The following estimation model is used:

$$
\operatorname{Prob}\left(P I_{t}=1\right)=\Phi\left(a g_{t-1}+\operatorname{brev} Y_{t-1}+c T O T g_{t-1}+d P I_{t-1}+\text { const }\right),
$$

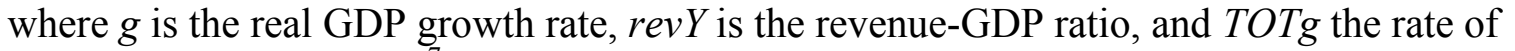
change in terms of trade.

The results of the Probit estimation are presented in Table 4. The impact of the revenue-GDP ratio and changes in terms of trade are statistically significant. ${ }^{8}$ A decline of the revenue-GDP ratio by 1 percentage point raises the probability of a coup by about

\footnotetext{
${ }^{7}$ Some studies suggest that conflicts in neighboring countries can also increase the probability of a coup; unfortunately the data do not exist to test this hypothesis. We attempted to partially control for this effect by including a dummy variable for conflicts in the Democratic Republic of Congo, constructed by Akitoby and Cynyabuguma (2004). To do so did not change the estimated coefficients, although the estimates were somewhat noisier.

${ }^{8}$ Given the correlation between per capita real GDP and revenue-GDP ratio, it is possible that the latter potentially captures the impact of lower per capita real GDP on political instability. Adding per capita real GDP into the estimation leaves the coefficient on revenue virtually unchanged, although it loses its statistical significance at the 10 percent level. Per capita real GDP is also not significant at the 10 percent level when substituted for the revenue-GDP ratio in the estimation. These suggest that revenue is a appropriate variable to include in the Probit estimation.
} 
3 percent. The two possible transmission channels are as follows. The accumulation of salary arrears or insufficient provision of basic social services could be a significant trigger for coup attempts. ${ }^{9}$ However, it is also possible that low revenues reflect a more general weakening of the country's institutions, which in turn raises political instability. ${ }^{10}$ The impact of terms of trade shocks, while modest, is statistically significant, in that a worsening of terms of trade by 10 percent raises the probability of a coup by about $4 \frac{1}{2}$ percent. Possible explanations for the role of terms-of-trade shocks include the following. First, a negative shock may weaken key economic sectors (such as cotton, diamond mining, and forestry), which might in turn trigger political instability (for example, because the incumbent is seen as unable to cope with the crisis). Second, adverse shocks can reduce the resources available for bribery. The country's main export products, diamonds and wood, are also its main sources of corruption. ${ }^{11}$ Negative terms of trade shocks may lower the rent associated with the export of these commodities and the resources available to corrupt politicians for easing their patronage networks, thus weakening their political position. The coefficient on past real GDP growth has the expected sign (poor growth translates into more instability), but is statistically insignificant. Finally, a coup attempt in a given year is estimated to raise the probability of another coup in the next period (by about 11 percent), but this effect is not statistically significant.

Table 4. Central African Republic: Probit Estimation of the Propensity of Political Instability

\begin{tabular}{|l|c|c|c|}
\hline Variable & Coefficient & $t$-ratio & Slope $^{12}$ \\
\hline Real GDP growth $\left(g_{t-1}\right)$ & -6.770 & 1.24 & -1.21 \\
\hline Revenue-GDP ratio $\left(r e v Y_{t-1}\right)$ & -0.167 & $2.68^{* *}$ & -3.01 \\
\hline Political instability, previous year $\left(\right.$ PI $\left._{t-1}\right)$ & 0.605 & 1.85 & 10.8 \\
\hline Rate of change in terms of trade $\left(\right.$ TOTg $\left._{t-1}\right)$ & -4.32 & $3.78^{* * *}$ & -0.46 \\
\hline Constant (const) & 0.822 & 0.48 & $\mathrm{n} / \mathrm{a}$ \\
\hline
\end{tabular}

Note: $* * *$ and $* *$ indicate significance at the 5 and 10 percent levels, respectively.

${ }^{9}$ Time series for the corresponding variables are nonexistent.

${ }^{10}$ The PRS Group compiles data measuring institutional quality for many countries, including some in sub-Saharan Africa. The C.A.R. is not covered. The estimation cannot directly control for institutional quality.

${ }^{11}$ See Dietrich (2002) on the influence of diamonds on governance in the C.A.R.

12 The slope is the marginal effect of the variable on the probability of a coup. 
Figure 6 plots the probability of a coup attempt predicted by our model. It shows that the latter captures the four main clusters of instability (late 1970s/early 1980s, early 1990s, mid-1990s, and early 2000s) relatively well. It does also, however, predict high probability of unrest in the late 1980s, although there was no coup attempt at that time. Overall, these results suggest that the inability of the government to raise sufficient revenues (and/or, possibly, to maintain institutional quality) and adverse terms of trade shocks played a significant role in the country's political instability.

While these results should be treated with caution, they may have some possible policy implications. They may suggest that improving the C.A.R.'s capacity to mobilize domestic revenue, to diversify the economy (to make it less vulnerable to terms of trade shocks), and to fight corruption could help to reduce the recurrence of adverse political events in the country.

Figure 6. Central African Republic: Predicted Probability of an Attempted Coup or Rebellion, 1967-2002

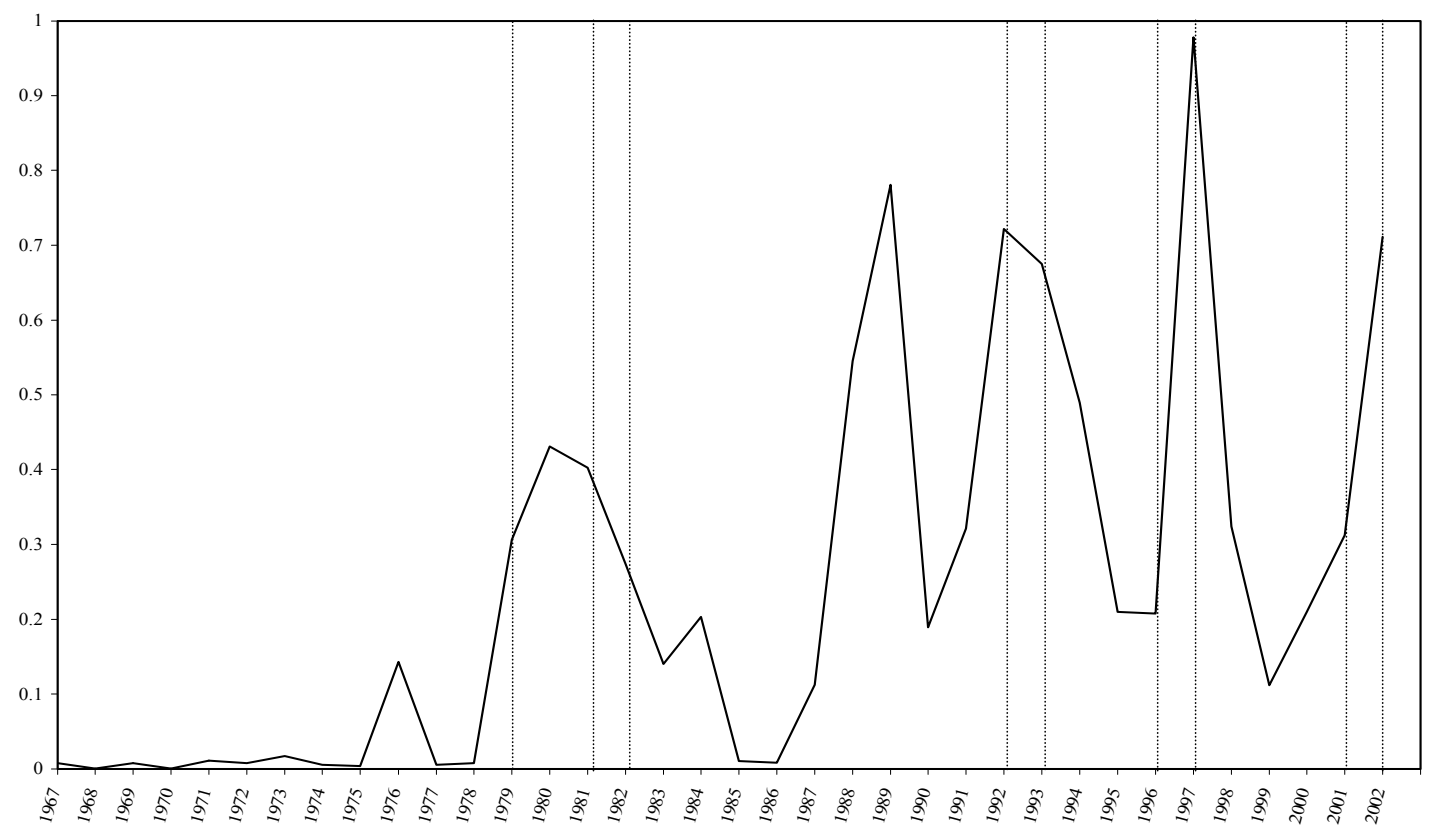

Note: The vertical lines correspond to attempted coups or rebellion.

\section{Growth Determinants}

This section investigates the determinants of growth in the C.A.R. and, in particular, the possible impact of political instability, using a version of the neoclassical growth model that takes the following form:

$$
G_{t}=\operatorname{Inv} Y_{t}+\text { BudY }_{t}+R E R g_{t}+\operatorname{TOTg}_{t}+C_{t}+P I_{t}+\text { Popug }_{t}+v_{t},
$$


where $G_{t}$ is real GDP growth; $\operatorname{Inv} Y_{t}$ is the investment-GDP ratio; $B u d Y_{t}$ is the budget balanceGDP ratio; $R E R g_{t}$ and $\mathrm{TOTg}_{t}$ are the rates of change in real effective exchange rate and the terms of trade, respectively; $C_{t}$ is the per capita real GDP growth in neighboring countries; ${ }^{13}$ $P I_{t}$ is a variable measuring political instability; Popug $_{t}$ is population growth; and $v_{t}$ is a random disturbance term. Equation (2) is estimated using annual data for the period 19672002.

The empirical results are presented in Table 5 below. In line with previous studies ${ }^{14}$ on sub-Saharan Africa, the impact of investment on growth in the C.A.R. is statistically significant. In addition, the C.A.R. appears particularly vulnerable to shocks from neighboring countries. A decrease by 1 percent in the weighted per capita real GDP growth rate in neighboring countries reduces per capita real GDP growth in the C.A.R. by about 0.35 percent. Changes in the real effective exchange rate - an indicator of external competitiveness - and in terms of trade have the expected sign, but are not statistically significant. The dummy variable for political instability has the expected negative sign (an attempted coup reduces real GDP growth by about half a percent), but it also is not statistically significant. The latter could be due to the fact that most of the adverse military events in the C.A.R. have been relatively low in intensity, limiting the scale of immediate economic disruption. It is also possible that the impact of political instability on growth is registered indirectly through the investment channel. In any event, the frequency of political instability has created an unstable economic environment, which has discouraged investment and annihilated prospects for long-term growth.

These results are rather robust to the impact of additional variables. Fosu (2001) argues that political instability can have an impact on economic growth, not only directly but also through the efficiency with which factors of production affect growth. This hypothesis is tested by adding variables $I n v Y^{*} P I$ and Popug ${ }^{*} P I$ into the regression. Both variables are statistically insignificant, and adding them in the regression does not affect the results. It is also possible that changes in the real exchange rate affect growth with a lag. With this in mind, we then add the corresponding variable into the regression and find that the effect of lagged changes in the real exchange rate on growth is statistically insignificant, so that the core results remain unchanged. Finally, we add a constant term into the regression, and find that the impact of the investment ratio, while remaining positive, loses its statistical significance at conventional levels of confidence.

${ }^{13}$ These border countries are Cameroon, Chad, the Republic of Congo, the DRC, and Sudan. $C_{t}$ is measured as the growth rate of the weighted per capita real GDP of these countries expressed in 1995 constant U.S. dollars. 1995 GDP weights are used.

${ }^{14}$ See, for example, Ghura and Hadjimichael (1996), and Akitoby and Cynyabuguma (2004). 
Table 5. Central African Republic: Determinants of Economic Growth, 1967-2002 $2^{15}$

\begin{tabular}{|l|c|c|}
\hline Variable & Coefficient & t-value \\
\hline Investment-GDP ratio (InvY) & 0.2857 & $2.92^{* * *}$ \\
\hline $\begin{array}{l}\text { Budget balance-GDP ratio } \\
\text { BudY })\end{array}$ & 0.2516 & 0.97 \\
\hline $\begin{array}{l}\text { Rate of change in real exchange } \\
\text { rate }(\text { RERg) }\end{array}$ & -0.0758 & -1.31 \\
\hline $\begin{array}{l}\text { Rate of change in terms of trade } \\
\text { TOTg) }\end{array}$ & 0.0449 & 0.89 \\
\hline Economic contagion $(C)$ & $0.3688)$ & $2.37 * * *$ \\
\hline Political instability $(P I)$ & -0.5163 & -0.38 \\
\hline Population growth $($ Popug $)$ & -0.5077 & -1.45 \\
\hline
\end{tabular}

*** indicates significance at the 5 percent level.

\section{Conclusions}

This paper analyzes the political instability and economic growth nexus in the C.A.R. during the period 1967-2002. Since gaining independence in 1960, the C.A.R. economy has intermittently been adversely affected by political instability and social unrest. Military coups, army rebellions, and extended labor disputes, combined with poor macroeconomic management and weak governance, have prevented the development of the country's rich and diverse endowment in natural resources and have led to deteriorating economic and social performance. In particular, chronic weak revenue performance led to the accumulation of domestic wage and external debt arrears and the degradation of basic social services. The accumulation of large arrears on and the irregular payments of wage to civil servants and military personnel led to prolonged labor strikes and army rebellions.

Empirical results first show that a low domestic revenue-GDP ratio and an adverse terms of trade shock significantly raise the probability of a coup. Weak revenue performance undermines the government's ability to pay civil servants' wages and to provide basic social services, which may raise frustration among the population and trigger political instability.

${ }^{15}$ The $R$-square of the regression is 0.37 . We check for serial correlation of the disturbances by running a Durbin-Watson test. The Durbin-Watson statistics is 2.88 , which is greater than the 5 percent upper bound for our parameters (1.9). We therefore cannot reject the null of no autocorrelation. 
Insufficient economic diversification and weak institutions (that allow corruption) also leave the country vulnerable to terms of trade shocks, which may raise political instability.

Economic growth is positively influenced by increases in investment, but adversely affected by a slowdown in economic activity in neighboring countries. A second conclusion is that the direct impact of political instability on growth is not significant once account is taken of domestic investment in the C.A.R. and economic performance in neighboring countries.

These results suggest that efforts to enhance the government's capacity to mobilize revenue would lower the probability of conflicts along with bringing economic benefits on its own. In a transitional period - in which internal efforts are being made to raise domestic revenues to a level high enough for the government to pay public employee salaries and offer basic services - the international community could play a role by offering budgetary support. Also, the diversification of the country's economic base would not only make its economy less vulnerable to external shocks, but would also reduce the propensity of terms of trade shocks to fuel political instability. While such efforts cannot substitute for building the necessary strong and efficient institutions, they might nonetheless help the country escape the poverty and governance trap in which it has been caught for several decades.

Finally, the results indicate that efforts in neighboring countries, such as the DRC, to resolve conflicts and get their economies back on the path of sustained economic growth would be beneficial for the C.A.R.'s economic performance. 


\section{References}

Akitoby, Bernardin, and Matthias Cynyabuguma, 2004, "Sources of Growth in the Republic of the Congo: A Retrospective and Prospects," IMF Working Paper (forthcoming; Washington: International Monetary Fund).

Collier, Paul, 1999, "On the Economic Consequences of Civil War," Oxford Economic Papers, Vol. 51 (January), pp. 163-83.

Collier, Paul and Anke Hoeffler, 2002, "Greed and Grievance in African Civil Wars," CSAE Working Paper No. WPS/2002-01 (Oxford: Centre for African Economies).

Collier, Paul and others, 2003, Breaking the Conflict Trap: Civil War and Development Policy, (New York: Oxford University Press for the World Bank).

Dietrich, Christian, 2002, "Hard Currency: The Criminalized Diamond Economy of the Democratic Republic of Congo and its Neighbors," Occasional Paper 4 (Ottawa: Partnership Africa-Canada, International Peace Information Service, Network for Justice and Development).

Easterly, William, and Ross Levine, 1997, “Africa's Growth Tragedy: Policies and Ethnic Divisions," Quarterly Journal of Economics, Vol. 112 (November), pp. 1203-50.

Elbadawi, Ibrahim, and Nicholas Sambanis, 2000, "Why Are There So Many Civil Wars in Africa? Understanding and Preventing Violent Conflict," Journal of African Economies, Vol. 9 (October), pp. 244-69.

Fosu, Augustin Kwasi, 2001, "Political Instability and Economic Growth in Developing Economies: Some Specification Empirics," Economics Letters, Vol. 70 (February), pp. 289-94.

Ghura, Dhaneshwar, and Michael T. Hadjimichael, 1996, "Growth in Sub-Saharan Africa," Staff Papers, International Monetary Fund, Vol. 43 (September), pp. 605-34.

Gudmundsson, Ragnar, 2004, "Alleviating Poverty in Post Conflict Cases: a Survey of the Literature," in From Conflict to Reconstruction-Main Lessons and Challenges for Sub-Saharan Africa-The Case of the Democratic Republic of Congo, ed. by Jean A.P. Clément (forthcoming; Washington: International Monetary Fund).

Leite, Carlos, and Jens Weidmann, 1999, "Does Mother Nature Corrupt? Natural Resources, Corruption and Economic Growth," IMF Working Paper WP/99/85 (Washington: International Monetary Fund).

Mauro, Paulo, 1995, “Corruption and Growth,” Quarterly Journal of Economics, Vol. 90, pp. 681-712. 
Sachs, Jeffrey, and Andrew Warner, 1997, "Sources of Slow Growth in African Economies," Journal of African Economies, Vol. 6, (No. 3), pp. 335-76.

Sambanis, Nicholas, 2003, "Using Case Studies to Expand the Theory of Civil War," CPR Working Paper No. 5 (Washington: World Bank).

Tornell, Aaron, and Philip Lane, 1999, "Voracity Effect," American Economic Review, Vol. 89 (March), pp. 22-46.

Yartey, Charles, 2004, "The Economics of Civil Wars in Sub-Saharan Africa," in From Conflict to Reconstruction-Main Lessons and Challenges for Sub-Saharan AfricaThe Case of the Democratic Republic of Congo, ed. by Jean A.P. Clément (forthcoming; Washington: International Monetary Fund). 